\title{
The antigenotoxic activity of latex from Himatanthus articulatus
}

\author{
Sebastião de O. Rebouças, Juliana da Silva, Aline A. Groff, \\ Emilene A. Nunes, Martus Ianistcki, Alexandre de B. F. \\ Ferraz*
}

Programa de Pós-graduação em Genética e Toxicologia Aplicada, Universidade Luterana do Brasil.

\begin{abstract}
Himatanthus articulatus (Vahl) Woodson (Apocynaceae) is a native plant to the Amazon popularly used to treat ulcers, tumors, inflammations, cancer, syphilis and malaria. The aim of the present study was to investigate the in vivo genotoxic/antigenotoxic and mutagenic potential of this plant, using the comet and the micronucleus assays in mice. Female and male adult mice were treated with different doses of $H$. articulatus latex by gavage for two consecutive days. For the experiments, the latex was serially diluted with water to $1: 2(\mathrm{D} 1) ; 1: 4\left(\mathrm{D}^{1 / 2}\right)$ and 1:8 $\left(\mathrm{D}^{1 / 4}\right)$ and administered to the animals. The blood slides were exposed to hydrogen peroxide (ex vivo) to evaluate antigenotoxic effect. Under the experimental conditions used in this study, the latex of $H$. articulatus did not increase the frequency of DNA damage as measured by the comet assay and micronucleus test in treated mice, indicating a non-genotoxic and non-mutagenic activity. In relation to the antigenotoxicity, latex exerted protective effect against DNA damage induced by hydrogen peroxide. Therefore, our results add new information about the antigenotoxic potential of $H$. articulatus latex, which is popularly used in the Amazon to treat different pathologies.
\end{abstract}

Revista Brasileira de Farmacognosia Brazilian Journal of Pharmacognosy 22(2): 389-396, Mar./Apr. 2012

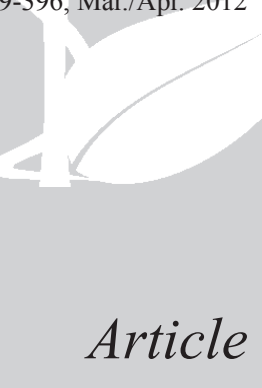

Received 19 Apr 2011

Accepted 30 Sep 2011

Available online 29 Nov 2011

Keywords:

antigenotoxic

comet assay

genotoxic

Himatanthus articulatus

latex

ISSN 0102-695X http://dx.doi.org/10.1590/S0102 $695 X 2011005000216$

\section{Introduction}

The biological properties of latex are always a mystery. Even in opium, the best known example of medicinal latex and the most powerful analgesic medicine, dual effects such as dependence and addiction have been observed concomitantly (Nicolaou \& Montagnon, 2008). Several studies have been published about latex properties, while some papers have reported toxic effects such as keratoconjunctivitis (Shlamovitz et al., 2009), mutagenic action (Lopes et al., 2004), irritant activity to skin (Hohmann \& Molnár, 2004), cytotoxicity (Wang et al., 2008) other papers present pharmacological, anti-ulcer (Bharti et al., 2010), antinociceptive (Soares et al., 2005), anti-inflammatory (Fernandez-Arche et al., 2010), and analgesic (Dewan et al., 2000) activities. The latex consumption is one of the innumerable ways that medicinal plants are used by the popular medicine in Brazil.

In South America, research has described the use of the latex from distinct species of the Apocynaceae genus, such as Plumeria, Allamanda and Himatanthus. The latex from Himatanthus sucuuba showed important biological properties such as anti-inflammatory and analgesic activities (De Miranda et al., 2000), apart from the role it plays in the treatment of tumors, ulcers, asthma and tuberculosis (Suffredini \& Daly, 2004), as well as the antileishmanial activity (Soares et al., 2010). This genus is widely used in phytotherapeutic treatments in distinct South American countries (Milliken, 1997; Suffredini \& Daly, 2004). The pure latex of H. articulatus or diluted in water is frequently consumed to treat antifungal and antibacterial infections (Sequeira et al., 2009), ulcers, tumors, inflammations and cancer (Coelho-Ferreira, 2009), syphilis (Barreto et al., 1998) and malaria (Milliken, 1997).

Several parts of this plant, commonly known as sucuba, are usually sold in stalls and herbal healers in the north, northeast and west-central Brazil (Pinto \& Maduro, 2003). However, in spite of this popularity, only one phytochemical study has been published about extracts from the bark, leaves and latex of $H$. articulatus, which reported the isolation and identification of terpenes and iridoids (Barreto et al., 1998). Chemical compositions of latex from distinct Himatanthus species described by different studies are presented in Chart 1.

Considering the absence of studies on the toxic effects of this plant, the aim of the present study was to evaluate the genotoxic/antigenotoxic and mutagenic activities of latex from $H$. articulatus, using the comet assay in blood and the micronucleus assay in the bone marrow and blood of mice. 
Chart 1: Chemical constituents from latex of Himatanthus species.

\begin{tabular}{|c|c|c|c|}
\hline Species & Chemical isolate & Class & Author \\
\hline H. articulatus & $\begin{array}{l}\alpha \text {-amyrin-3} \beta \text { - } O \text {-cinnamoyl, } \beta \text {-amyrin- } 3 \beta \text { - } O \text {-cinnamoyl, } \\
\text { acetate of lupeol, cinnamate of lupeol, cycloartenol }\end{array}$ & Terpenes & Barreto et al., 1998 \\
\hline H. fallax & $\begin{array}{l}\text { isoplumericin, plumericin, plumieride, pinoresinol } \\
\text { matairesinol, } 7(R) \text {-methoxy-8-epi-matairesinol }\end{array}$ & Iridoids & Abdel-Kader, 1997 \\
\hline \multirow[t]{7}{*}{ H. sucuuba } & $\begin{array}{l}\text { 15-demethylisoplumieride acid, } 15 \text {-demethylplumieride } \\
\text { acid, plumieride, isoplumieride }\end{array}$ & Iridoids & Barreto et al., 2007 \\
\hline & 15-demethylplumieride acid, plumieride, isoplumieride & Iridoids & Silva et al., 2007 \\
\hline & lupeol acetate, $\alpha$-amyrin and lupeol cinnamates & Terpenes & De Miranda et al., 2000 \\
\hline & $\begin{array}{l}\text { cis-polyisoprene, arabinose, glucose, xylose, rhamnose and } \\
\text { galactose, } \mathrm{Na}, \mathrm{Mg}, \mathrm{Al}, \mathrm{K}, \mathrm{Ca}, \mathrm{Mn}, \mathrm{Fe}, \mathrm{Sr}\end{array}$ & Miscellaneous & Silva et al., 2003 \\
\hline & $\begin{array}{l}\alpha \text {-amyrin cinnamates, } \beta \text { - amyrin cinnamates, lupeol } \\
\text { cinnamates, lupeol acetate }\end{array}$ & Terpenes & Silva, 2000 \\
\hline & $\begin{array}{l}\text { plumericin, isoplumericin, plumieride, isoplumieride, } 15 \text { - } \\
\text { demethylisoplumieride, } 15 \text {-demethylplumieride }\end{array}$ & Iridoids & Silva, 2000 \\
\hline & catechol, gallic acid, myricetrin, quercitrin & Phenolic compounds & Silva, 2000 \\
\hline H. bracteatus; & plumieride, isoplumieride & Iridoids & Ferreira et al., 2009 \\
\hline $\begin{array}{l}\text { H. stenophyllus; } \\
\text { H. sucuuba }\end{array}$ & & & \\
\hline
\end{tabular}

\section{Materials and Methods}

\section{Plant material}

Himatanthus articulatus (Vahl) Woodson, Apocynaceae, latex was collected from Campus Cauame (Monte Cristo), Federal University of Roraima (UFRR) in August, 2009 (GPS coordinates $\left.2^{\circ} 51^{\prime} 48^{\prime \prime} \mathrm{N}, 60^{\circ} 43^{\prime} 01^{\prime \prime} \mathrm{W}\right)$. A voucher specimen was deposited at the Herbarium of the National Institute of Amazonian Research, INPA Manaus, Amazonas, Brazil, recorded under number 214743.

\section{Preparation of samples}

Due to the impossibility to administer the pure latex by gavage, it was mixed with water $(1: 1 ; \mathrm{v} / \mathrm{v})$ and stored in a refrigerator at $4{ }^{\circ} \mathrm{C}$. For the experiments, the latex was serially diluted with water to 1:2 (D1); 1:4 (D $\left.{ }^{1 / 2}\right)$ and 1:8 $\left(\mathrm{D}^{1 / 4}\right)$ and administered to the animals.

\section{Materials/chemicals and reagents}

Cyclophosphamide (CP, Genuxal, Asta Medica, Lot. n.807034) was used as a positive control.

\section{Animals and treatments}

A total of fifty male and female mice (CF-1, 5 weeks old, $29.23 \pm 1.99 \mathrm{~g}$ ) from our breeding colony, free of specific pathogens were used. Animals were housed in cages, received commercial standard mouse cube diet (Nuvilab, CR1, Moinho Nuvipal Ltda, Curitiba, PR,
Brazil) and water ad libitum, under a 12-h light/dark cycle, temperature of $23 \pm 3{ }^{\circ} \mathrm{C}$ and relative humidity of about $60 \%$. All experimental procedures were carried out in accordance with the Guide for the Care and Use of Laboratory Animals of the National Institutes of Health (NIH). This study was approved by an internal ethics committee animal experimentation of the Lutheran University of Brazil (CEP-ULBRA 2008-018A).

The animals were divided to form groups with ten individuals per group: (five male and five female), and treated by gavage with water (negative control) or latex (D1; $\mathrm{D}^{1 / 2} ; \mathrm{D}^{1 / 4}$ ) and the positive control group (treated with cyclophosphamide by gavage $25 \mathrm{mg} / \mathrm{kg}$ ). All animals received treatment for two consecutive days (OECD, 1997). For the comet assay, peripheral blood samples were obtained 3, 6 and $48 \mathrm{~h}$ after the beginning of the experiment from mouse tail tips (about $15 \mu \mathrm{L}$ ) by means of small incision and immediately mixed with heparin sodium (7 $\mu \mathrm{L})$. The animals were sacrificed by cervical dislocation after $48 \mathrm{~h}$, when blood and bone marrow were collected for comet assay and micronucleus test.

DNA damage was induced ex vivo by exposing the blood cells to $\mathrm{H}_{2} \mathrm{O}_{2} 0.25 \mathrm{mM}(0-250 \mu \mathrm{mol} / \mathrm{L}$ diluted in PBS) on slides. In order to establish the protective ability of the latex against the oxidative stress induced by $\mathrm{H}_{2} \mathrm{O}_{2}$, the comet assay was performed with all the animals preexposed to latex. The slides were exposed to $\mathrm{H}_{2} \mathrm{O}_{2}$ for 5 min (ex vivo) (Lovell \& Omori, 2008). Antigenotoxic potential was expressed as described in Kapiszewska et al. (2005), as percentage inhibition of damage index (DI) according to the expression: (I\%): percentage of inhibition of $\mathrm{DI}=\left[\mathrm{H}_{2} \mathrm{O}_{2}\right.$ DI mean-DI mean of the extract with $\left.\mathrm{H}_{2} \mathrm{O}_{2}\right]$ / 
$\left[\mathrm{H}_{2} \mathrm{O}_{2}\right.$ DI mean-DI mean negative control] x 100.

\section{Comet assay}

The alkaline comet assay was performed as described by Singh et al. (1988) and as modified in Da Silva et al. (2000). Cells were obtained according to the method described by Tice (1995), where whole heparinized blood was utilized, and bone marrow perfuse of femur was homogenized with fetal bovine serum. Cells isolated from tissues $(10 \mu \mathrm{L})$ were embedded in $95 \mu \mathrm{L}$ of $0.75 \%(\mathrm{w} / \mathrm{v})$ low melting point agarose (Gibco BRL) and the mixture added to a microscope slide pre-coated with $1.5 \%(\mathrm{w} / \mathrm{v})$ of normal melting point agarose and covered with a coverslip. All slides were prepared in quadruplicate. The slide was briefly placed on ice for agarose to solidify, and the coverslip carefully removed. Then, slides were exposed to either PBS (two slides) or $0.25 \mathrm{mM}$ freshly prepared $\mathrm{H}_{2} \mathrm{O}_{2}$ solution (ex vivo treatment) for $5 \mathrm{~min}$, at $4{ }^{\circ} \mathrm{C}$ ( 2 slides) (Lovell \& Omori, 2008). Next, the slides were immersed in lysis solution $(2.5 \mathrm{M} \mathrm{NaCl}, 100 \mathrm{mM}$ EDTA and $10 \mathrm{mM}$ Tris, $\mathrm{pH} 10.0-10.5)$ containing freshly added $1 \%$ triton $\mathrm{X}-100$ and $10 \%$ dimethyl sulfoxide (DMSO) for at least 1 h at $4{ }^{\circ} \mathrm{C}$.

Subsequently, the slides were incubated in freshly made alkaline buffer $(300 \mathrm{mM} \mathrm{NaOH}$ and $1 \mathrm{mM}$ EDTA, $\mathrm{pH}>13$ ) for $20 \mathrm{~min}$ for DNA unwinding, and electrophoresed in the same buffer. The electrophoresis conditions were $15 \mathrm{~min}$ at $300 \mathrm{~mA}$ and $25 \mathrm{~V}(0.7 \mathrm{~V} /$ $\mathrm{cm})$. All these steps were carried out under dim indirect light.

Following electrophoresis, the slides were neutralized in $400 \mathrm{mM}$ Tris $(\mathrm{pH} 7.5)$ and fixed $(15 \% \mathrm{w} / \mathrm{v}$ trichloroacetic acid, 5\% w/v zinc sulfate, 5\% glycerol), washed in distilled water and dried overnight. The gels were re-hydrated for $5 \mathrm{~min}$ in distilled water, and then stained for $15 \mathrm{~min}\left(37^{\circ} \mathrm{C}\right)$ with a solution containing the following sequence: $34 \mathrm{~mL}$ of Solution B $(0.2 \% \mathrm{w} / \mathrm{v}$ ammonium nitrate, $0.2 \% \mathrm{w} / \mathrm{v}$ silver nitrate, $0.5 \% \mathrm{w} / \mathrm{v}$ tungstosilicic acid, $0.15 \% \mathrm{v} / \mathrm{v}$ formaldehyde, $5 \% \mathrm{w} / \mathrm{v}$ sodium carbonate) and $66 \mathrm{~mL}$ of Solution A (5\% sodium carbonate). The staining was stopped with $1 \%$ acetic acid and the gels were air-dried (Nadin et al., 2001) and analyzed using a microscope.

Images of 100 randomly selected cells (50 cells from each of two replicate slides) were analyzed from each animal; all sides were coded for blind analysis (Lovell \& Omori, 2008). Cells were also visually scored according to tail size into five classes ranging from undamaged (0) to maximally damaged (4), resulting in a single DNA damage score for each animal, and consequently to each studied group. Therefore, the damage index can range from 0 (completely undamaged, 100 cells x 0 ) to 400 (with maximum damage, $100 \times 4$ ). The frequency (DF in \%) was calculated for each sample based on the number of cells with tail versus those without.

\section{Micronucleus assay}

The micronucleus assay was performed according to the US Environmental Protection Agency Gene-Tox Program (Mavournin et al., 1990) and as modified in Da Silva et al. (2000). Whole blood smears were prepared on slides after $48 \mathrm{~h}$, when animals were killed by cervical dislocation.

The bone marrow was extracted from the two femurs. Smears were prepared directly on slides with bone marrow and blood, two per animal and per tissue. Bone marrow smear was prepared with a drop of fetal calf serum. The slides were stained with $5 \%$ Giemsa, airdried and coded for blind analysis. To avoid false negative results and as a measure of toxicity in bone marrow, the ratio of polychromatic erythrocytes to normochromatic erythrocytes (PCE/NCE) was scored in 1,000 cells. The incidence of micronuclei (MN) was observed in 2,000 PCE and 2,000 peripheral blood reticulocytes (RET) for each animal (i.e. 1,000 from each of the two slides prepared from the duplicate), using bright-field optical microscopy under 200-1000× magnification. All sides were coded for blind analysis. The test groups were compared to the respective negative controls for gender, separately and in combination.

\section{Data analysis}

Results are expressed as means \pm SD and statistical significance between the five groups and gender was determined by One-Way Analysis of Variance (ANOVA, Kruskal-Wallis test). In all comparisons, $p<0.05$ was considered statistical significance.

\section{Results}

The comet assay data for genotoxicity at different exposure times (3,6 and $48 \mathrm{~h}$ ) per gender and per group are summarized in Table 1. No differences were observed for the different exposure times in comparison to negative control. Only the positive control presented differences in mean DI, with more damaged cells than the negative control $(p<0.05$, Kruskal-Wallis test). No significant differences were found between sex for different exposure groups and exposure times.

Results of the micronucleus test in peripheral blood and bone marrow cells collected after $48 \mathrm{~h}$ are shown in Table 2. The Kruskal-Wallis Test revealed that mean micronuclei frequency in peripheral blood and bone marrow cells was significantly higher only in the positive control group, when compared with the negative control. No differences in micronucleus frequency were observed 
between groups in the blood and bone marrow tissues, neither in PCE/NCE ratio. No difference was observed between genders.

We also checked the antigenotoxicity activity after $\mathrm{H}_{2} \mathrm{O}_{2}$ challenge (Table 3). The data in Table 4 indicate that the intervention with latex significantly increased the ability to remove the DNA damage generated by $\mathrm{H}_{2} \mathrm{O}_{2}$ in blood cells isolated from animals treated with latex (D1: 100\%) after 48 h. When antigenotoxic potential was expressed as described in Kapiszewska et al. (2005), the concentration of latex used for the 48-h treatment caused a significant reduction in DNA damage. In comparison to the 3-h treatment, a DNA damage modulation of $12.85 \%$ was observed in the 3-h treatment, while for the $48-\mathrm{h}$ treatment modulation was $79.02 \%$.

Table 1. Cytogenetic parameter (mean \pm SD) for blood, samples of exposed animals to latex, cyclophosphamide (positive control) and water (negative control). In each group: $\mathrm{n}=10$ (five male and five female), 100 cells/animal.

\begin{tabular}{|c|c|c|c|c|c|c|c|}
\hline \multirow{3}{*}{ Groups } & \multirow{3}{*}{ Gender } & \multicolumn{6}{|c|}{ Comet assay parameters per exposition period } \\
\hline & & \multicolumn{3}{|c|}{ Damage Index (DI) } & \multicolumn{3}{|c|}{ Damage Frequency (DF) } \\
\hline & & $3 \mathrm{~h}$ & $6 \mathrm{~h}$ & $48 \mathrm{~h}$ & $3 \mathrm{~h}$ & $6 \mathrm{~h}$ & $48 \mathrm{~h}$ \\
\hline \multirow{4}{*}{$\begin{array}{l}\text { Negative } \\
\text { Control }\end{array}$} & Male & $6.67 \pm 1.53$ & $10.00 \pm 2.65$ & $7.20 \pm 3.27$ & $6.67 \pm 1.53$ & $9.00 \pm 2.00$ & $6.40 \pm 2.97$ \\
\hline & Female & $5.00 \pm 2.00$ & $9.00 \pm 6.08$ & $10.60 \pm 1.14$ & $4.67 \pm 1.53$ & $6.67 \pm 3.79$ & $9.20 \pm 0.84$ \\
\hline & Group & $5.83 \pm 1.83$ & $9.50 \pm 4.23$ & $8.90 \pm 2.92$ & $5.17 \pm 1.47$ & $7.83 \pm 2.99$ & $7.80 \pm 2.53$ \\
\hline & Male & $10.33 \pm 1.53$ & $8.00 \pm 2.65$ & $5.00 \pm 2.35$ & $8.00 \pm 1.00$ & $7.00 \pm 1.00$ & $4.40 \pm 1.95$ \\
\hline \multirow[t]{3}{*}{ Latex $\mathrm{D}^{1 / 4}$} & Female & $13.00 \pm 1.53$ & $8.67 \pm 3.51$ & $7.40 \pm 2.10$ & $10.00 \pm 2.65$ & $5.67 \pm 2.08$ & $6.60 \pm 1.30$ \\
\hline & Group & $11.70 \pm 2.42$ & $8.33 \pm 2.80$ & $6.20 \pm 2.45$ & $9.00 \pm 2.10$ & $6.33 \pm 1.63$ & $5.50 \pm 2.38$ \\
\hline & Male & $12.67 \pm 1.53$ & $9.67 \pm 0.58$ & $5.60 \pm 1.82$ & $10.33 \pm 1.53$ & $7.33 \pm 1.20$ & $4.80 \pm 1.48$ \\
\hline \multirow[t]{3}{*}{ Latex D1/2 } & Female & $14.33 \pm 0.58$ & $7.00 \pm 1.73$ & $6.40 \pm 0.55$ & $12.67 \pm 0.58$ & $5.00 \pm 1.00$ & $5.60 \pm 0.89$ \\
\hline & Group & $13.50 \pm 1.38$ & $8.33 \pm 1.86$ & $6.00 \pm 1.33$ & $11.50 \pm 1.64$ & $6.20 \pm 2.00$ & $5.20 \pm 1.23$ \\
\hline & Male & $5.67 \pm 1.15$ & $9.33 \pm 4.73$ & $6.40 \pm 1.70$ & $5.33 \pm 0.58$ & $7.00 \pm 4.00$ & $5.60 \pm 1.42$ \\
\hline \multirow[t]{2}{*}{ Latex D1 } & Female & $6.67 \pm 2.52$ & $11.67 \pm 2.08$ & $8.00 \pm 2.35$ & $4.33 \pm 1.15$ & $8.33 \pm 1.53$ & $7.20 \pm 0.37$ \\
\hline & Group & $6.17 \pm 1.83$ & $10.50 \pm 3.51$ & $7.20 \pm 2.15$ & $4.83 \pm 0.98$ & $7.67 \pm 2.80$ & $6.40 \pm 1.51$ \\
\hline \multirow{3}{*}{$\begin{array}{l}\text { Positive } \\
\text { Control }\end{array}$} & Male & $53.67 \pm 5.51$ & $49.00 \pm 14.73$ & $40.60 \pm 8.08$ & $29.33 \pm 1.53$ & $34.00 \pm 6.24$ & $32.80 \pm 6.30$ \\
\hline & Female & $58.33 \pm 2.08$ & $60.00 \pm 16.46$ & $32.20 \pm 9.44$ & $35.00 \pm 9.64$ & $40.33 \pm 5.86$ & $25.40 \pm 2.70$ \\
\hline & Group & $56.00 \pm 4.52 * * *$ & $54.50 \pm 15.22 *$ & $36.40 \pm 9.40^{*}$ & $32.17 \pm 6.90^{* * *}$ & $37.17 \pm 6.43^{*}$ & $29.10 \pm 6.01 *$ \\
\hline
\end{tabular}

"Significant in comparison to negative control in the same exposure time at $p<0.05 ;{ }^{* * *} p<0.001$; by the Kruskal-Wallis test.

Table 2. Micronuclei mean $( \pm \mathrm{SD})$ in peripheral blood reticulocytes (MNRET) and bone marrow polychromatic erythrocytes (MNPCE) of mice exposed to latex, cyclophosphamide (positive control) and water (negative control). In each group: $\mathrm{n}=10$ (five male and five female), 2,000 cells/animal.

\begin{tabular}{|c|c|c|c|c|c|c|}
\hline \multirow{2}{*}{ Group } & \multirow{2}{*}{ Gender } & \multicolumn{2}{|c|}{ MNRET } & \multicolumn{2}{|r|}{ MNPCE } & \multirow{2}{*}{$\frac{\text { Ratio (PCE:NCE) }}{\text { Per group }}$} \\
\hline & & Per gender & Per group & Per gender & Per group & \\
\hline \multirow[t]{2}{*}{ Negative Control $^{\mathrm{c}}$} & Male & $1.2 \pm 0.45$ & \multirow{2}{*}{$1.4 \pm 0.52$} & $1.6 \pm 0.55$ & \multirow{2}{*}{$1.6 \pm 0.52$} & \multirow{2}{*}{$1.33 \pm 0.21$} \\
\hline & Female & $1.6 \pm 0.55$ & & $1.6 \pm 0.55$ & & \\
\hline \multirow[t]{2}{*}{ Latex D $1 / 4$} & Male & $1.4 \pm 0.89$ & \multirow{2}{*}{$1.4 \pm 1.07$} & $2.0 \pm 0.71$ & \multirow{2}{*}{$2.1 \pm 0.74$} & \multirow{2}{*}{$1.45 \pm 0.34$} \\
\hline & Female & $1.4 \pm 1.34$ & & $2.2 \pm 0.84$ & & \\
\hline \multirow[t]{2}{*}{ Latex $\mathrm{D}^{1 / 2}$} & Male & $1.4 \pm 0.89$ & \multirow{2}{*}{$1.7 \pm 1.10$} & $1.6 \pm 0.55$ & \multirow{2}{*}{$1.7 \pm 0.48$} & \multirow{2}{*}{$1.71 \pm 0.52$} \\
\hline & Female & $2.0 \pm 1.22$ & & $1.8 \pm 0.45$ & & \\
\hline \multirow[t]{2}{*}{ Latex D1 } & Male & $2.8 \pm 0.45$ & \multirow{2}{*}{$2.6 \pm 0.52$} & $1.2 \pm 0.84$ & \multirow{2}{*}{$1.4 \pm 0.70$} & \multirow{2}{*}{$1.42 \pm 0.71$} \\
\hline & Female & $2.4 \pm 0.55$ & & $1.6 \pm 0.55$ & & \\
\hline \multirow[t]{2}{*}{ Positive Control $^{\mathrm{b}}$} & Male & $12.2 \pm 2.77$ & \multirow{2}{*}{$11.9 \pm 1.91 * * *$} & $17.8 \pm 4.66$ & \multirow{2}{*}{$16.2 \pm 4.21 * * *$} & \multirow{2}{*}{$0.82 \pm 0.34$} \\
\hline & Female & $11.6 \pm 0.55$ & & $14.6 \pm 2.44$ & & \\
\hline
\end{tabular}

\footnotetext{
***Significant in comparison to negative control in same tissue at $p<0.0001$; by the Kruskal-Wallis test.
} 
Table 3. Comet assay in peripheral blood leukocytes of mice treated with latex (D1) with and without hydrogen peroxide $(0.25$ $\mathrm{mM})($ ex vivo). Values are expressed as mean $\pm \mathrm{SD}$.

\begin{tabular}{|c|c|c|c|c|c|c|c|c|c|c|}
\hline \multirow{4}{*}{ Groups } & \multirow{4}{*}{ Time } & \multirow{4}{*}{ Gender } & \multicolumn{8}{|c|}{ Comet assay parameters } \\
\hline & & & \multicolumn{4}{|c|}{ Damage Index (DI) } & \multicolumn{4}{|c|}{ Damage Frequency (DF) } \\
\hline & & & \multicolumn{2}{|c|}{ Without $\mathrm{H}_{2} \mathrm{O}_{2}$} & \multicolumn{2}{|c|}{ With $\mathrm{H}_{2} \mathrm{O}_{2}$} & \multicolumn{2}{|c|}{ Without $\mathrm{H}_{2} \mathrm{O}_{2}$} & \multicolumn{2}{|c|}{ With $\mathrm{H}_{2} \mathrm{O}_{2}$} \\
\hline & & & Per Gender & Per Group & Per Gender & Per Group & Per Gender & Per Group & Per Gender & Per Group \\
\hline \multirow{4}{*}{ Control } & \multirow{2}{*}{$3 \mathrm{~h}$} & Male & $3.60 \pm 2.79$ & $3.0 \pm 2.67$ & $147.40 \pm 18.09$ & $142.20 \pm 17.70$ & $3.20 \pm 2.28$ & $2.80 \pm 2.39$ & $63.80 \pm 11.39$ & $64.10 \pm 9.55$ \\
\hline & & Female & $2.40 \pm 2.70$ & & $137.00 \pm 17.61$ & & $2.40 \pm 2.70$ & & $64.40 \pm 8.68$ & \\
\hline & \multirow{2}{*}{$48 \mathrm{~h}$} & Male & $5.80 \pm 3.27$ & $4.10 \pm 3.21$ & $136.00 \pm 33.53$ & $127.90 \pm 24.60$ & $3.80 \pm 1.92$ & $3.00 \pm 2.16$ & $62.00 \pm 15.13$ & $59.00 \pm 17.69$ \\
\hline & & Female & $2.40 \pm 2.30$ & & $119.80 \pm 8.56$ & & $2.20 \pm 2.28$ & & $56.00 \pm 21.27$ & \\
\hline \multirow{4}{*}{ Latex D1 } & \multirow{2}{*}{$3 \mathrm{~h}$} & Male & $3.20 \pm 1.48$ & $3.70 \pm 1.60$ & $115.20 \pm 17.17$ & $124.30 \pm 17.00$ & $3.00 \pm 1.40$ & $3.40 \pm 1.50$ & $50.40 \pm 10.67$ & $56.80 \pm 11.24$ \\
\hline & & Female & $4.20 \pm 1.79$ & & $133.40 \pm 12.20$ & & $3.80 \pm 1.60$ & & $63.20 \pm 8.26$ & \\
\hline & \multirow{2}{*}{$48 \mathrm{~h}$} & Male & $7.00 \pm 3.32$ & $7.00 \pm 3.06$ & $15.40 \pm 4.98$ & $17.90 \pm 4.93^{\mathrm{a}, \mathrm{b}}$ & $5.60 \pm 2.30$ & $5.70 \pm 2.45$ & $14.40 \pm 5.05$ & $16.20 \pm 4.64^{\mathrm{a}, \mathrm{b}}$ \\
\hline & & Female & $7.00 \pm 3.16$ & & $20.40 \pm 3.78$ & & $5.80 \pm 2.86$ & & $18.40 \pm 3.29$ & \\
\hline
\end{tabular}

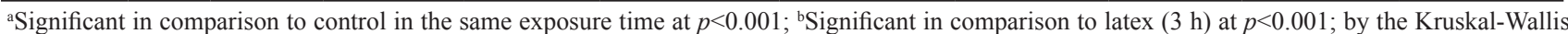
test.

\section{Discussion}

In this study, genotoxic and antigenotoxic activity of $H$. articulatus latex was tested in blood cells, and its mutagenic effect was assessed in bone marrow and blood cells in mice. The comet assay was used to detect recent DNA damage, such as single and double strand breaks, alkali-labile sites, DNA-DNA and DNA-protein crosslinks (Singh et al., 1988; Tice, 1995), while the micronucleus test was used to detect clastogenic/aneugenic activities, which leads to increasing micronucleus frequency, suggesting the occurrence of mutagenic effects at chromosomal level (Mavournin et al., 1990). The results obtained in this study showed no mutagenic nor genotoxic effects of the latex of $H$. articulatus (Table 2 and 3). Similarly, a study on latex of "Sangre de Drago", a red viscous latex extracted from Croton lechleri, Euphorbiaceae, cortex, no mutagenic activity was observed by means of the Ames/Salmonella test, on the Salmonella typhimurium strains T98 and T100, either with or without S9 activation (Rossi et al., 2003). Paiva et al. (2011) using several experimental methods to evaluate the mutagenic and genotoxic effects of Euphorbia tirucalli latex preparations, such as inductest, the Ames/ Salmonella test and the chromotest, showed that no mutagenic or genotoxic damages were induced by all samples studied. Another aspect that is in accordance with the low toxicity found is the high occurrence of iridoids such as plumericin in the latex of distinct Himatanthus species. This substance was shown to be weakly cytotoxic against Sc-7 strain of Saccharomyces cerevisiae (Abdel-Kader et al., 1997), an observation also reported by Aponte et al. (2009) against several mammalian cancer cell lines. No data on assessments of the genotoxicity or damage effects of different species of Himatanthus was found in the literature.
The putative antigenotoxic effect of latex was investigated in mice blood cells, ex vivo, before and after a hydrogen peroxide $\left(\mathrm{H}_{2} \mathrm{O}_{2}\right)$ treatment by the comet assay. Hydrogen peroxide causes DNA strand breakage by generating hydroxyl radicals close to the DNA molecule. Thus, antioxidant activity is assessed as the decreased induction of DNA breaks. Our results (Table 4) showed that animals treated with latex demonstrated an increase in cell resistance to DNA damage caused by $\mathrm{H}_{2} \mathrm{O}_{2}$-induced DNA strand breaks in blood cells, irrespective of the dose ingested $(48 \mathrm{~h}>3 \mathrm{~h})$.

The phytochemical composition of this latex can help understand this antigenotoxic effect in greater depth. The presence of terpenes and iridoids has been reported to occur in the latex of distinct Himatanthus species (Table 1). Terpenes such as lupeol derivatives are reported to afford a hepatoprotective effect against the toxic damages induced by cadmium. Metals like cadmium are known to induce lipid peroxidation (Sunitha et al., 2001). In addition, lupeol derivatives are believed to function by modulating processes associated with xenobiotic biotransformation, with the protection of cellular elements from oxidative damage, or with the promotion of a more differentiated phenotype in target cells (Nigam et al., 2007). It has been reported that lupeol and its derivatives can be exploited as prospective targets for development of novel chemotherapeutic agents for the prevention and/or treatment of cancer (Chaturvedi et al., 2008). The amyrin derivatives are other terpenic constituents of the latex of $H$. articulatus whose protective effects against damage induced by different compounds, like tetrachloromethane (Aimin et al., 1998), acetaminophen (Oliveira et al., 2005), and 12-O-tetradecanoylphorbol-acetate (Medeiros et al., 2007).

In a previous study, latex components such as iridoids (catalpol) were described to present 
hepatoprotective and anti-inflammatory properties (Dinda et al., 2009). This product was able to protect cell viability and reduce intracellular reactive oxygen species (ROS) formation in astrocytes from oxidant stress induced by $\mathrm{H}_{2} \mathrm{O}_{2}$, and may be an attractive candidate for the treatment of various neurodegenerative disorders associated with oxidative stress (Bi et al., 2008). Aucubin is another iridoid that was shown to have protective effects. Jin et al. (2008) demonstrated that this iridoid was able to control hyperglycemia and exert antioxidant protection of pancreatic $\beta$ cell, against damage induced by streptozootocin, being appointed by the authors as a preventive agent against diabetes mellitus. The pre-treatment with aucubin in human skin fibroblast cell lines showed a significant inhibition of ROS formation and malondialdehyde levels and increased cell viability and glutathione after exposure to UVB radiation (Ho et al., 2005).

Finally, it is well described that the presence of phenolic compounds in plant extracts contributes significantly to their antioxidant potential (Dudonné et al., 2009). For this reason, we also cannot rule out the possibility that the observed protection may be related to the presence of phenolic compounds (gallic acid, catechol, myricetrin and quercitrin) described by Silva (2000).

\section{Conclusions}

Under the experimental conditions used in this study, the latex of $H$. articulatus did not increase the frequency of DNA damage as measured by the comet assay and micronucleus test in treated mice, indicating a non-genotoxic and non-mutagenic activity. In relation to the antigenotoxicity, latex exerted protective effect against DNA damage induced by hydrogen peroxide. Therefore, our results add new information about the antigenotoxic potential of $H$. articulatus latex, which is popularly used in the Amazon to treat different pathologies.

\section{Acknowledgements}

This work was supported by Universidade Luterana do Brasil, Conselho Nacional de Desenvolvimento Científico e Tecnológico, and Fundação de Amparo à Pesquisa do Estado do Rio Grande do Sul, Brazil.

\section{References}

Abdel-Kader MS, Wisse J, Evans R, Van der Werff H, Kingston DGI 1997. Bioactive iridoids and a new lignan from Allamanda cathartica and Himatanthus fallax from the Suriname rainforest. J Nat Prod 60: 1294-1297.

Aimin H, Mingshi W, Hongyan H, Decheng Z, Lee K 1998. Hepatoprotective triterpenes from Sedum sarmentosum. Phytochemistry 49: 2607-2610.
Aponte JC, Vaisberg AJ, Rojas R, Sauvain M, Lewis WH, Lamas G, Sarasara C, Gilman RH, Hammond GB 2009. A multipronged approach to the study of peruvian ethnomedicinal plants: A legacy of the ICBG-Peru project. J Nat Prod 72: 524-526.

Barreto AS, Carvalho MG, Nery IA, Gonzaga L, Kaplan, MAC 1998. Chemical constituents from Himatanthus articulata. J Braz Chem Soc 9: 430-434.

Barreto AS, Amaral ACF, Silva JRA, Schripsema J, Rezende CM, Pinto AC 2007. 15-demethylisoplumieride acid, a new iridoid isolated from the bark of Plumeria rubra and latex of Himatanthus sucuuba. Quim Nova 30: 11331135.

Bharti S, Wahane VD, Kumar,VL 2010. Protective effect of Calotropis procera latex extracts on experimentally induced gastric ulcers in rat. $J$ Ethnopharmacol 127 : 440-444.

Bi J, Jiang B, Liu JH, Lei C, Zhang XL, An L 2008. Protective effects of catalpol against $\mathrm{H}_{2} \mathrm{O}_{2}$-induced oxidative stress in astrocytes primary cultures. Neurosci Lett 442: 224227.

Chaturvedi PK, Bhui K, Shukla Y 2008. Lupeol: Connotations for chemoprevention. Cancer Lett 263: 1-13.

Coelho-Ferreira M 2009. Medicinal knowledge and plant utilization in an Amazonian coastal community of Marudá, Pará State (Brazil). J Ethnopharmacol 126: 159-175.

Da Silva J, Freitas TRO, Marinho JR, Speit G, Erdtmann B 2000. An alkaline single-cell gel electrophoresis (comet assay) for environmental biomonitoring with native rodents. Genet Mol Biol 23: 241-245.

De Miranda ALP, Silva JRA, Rezende CM, Neves JS, Parrini SC, Pinheiro MLB, Cordeiro MC, Tamborini E, Pinto AC 2000. Anti-inflammatory and analgesic activities of the latex containing triterpenes from Himatanthus sucuuba. Planta Med 66: 284-286.

Dewan S, Sangraula H, Kumar VL 2000. Preliminary studies on analgesic activity of latex of Calotropis procera. $J$ Ethnopharmacol 73: 307-311.

Dinda B, Chowdhury D, Mohanta BC 2009. Naturally occurring iridoids, secoiridoids and their bioactivity. An updated review, Part 3. Chem Pharm Bull 57: 765-796.

Dudonné S, Vitrac X, Coutière P, Woillez M, Mérillon J 2009. Comparative study of antioxidant properties and total phenolic content of 30 plant extracts of industrial interest using DPPH, ABTS, FRAP, SOD, and ORAC assays. $J$ Agric Food Chem 57: 1768-1774.

Fernandez-Arche A, Saenz MT, Arroyo M, Puerta R, Garcia MD 2010. Topical anti-inflammatory effect of tirucallol, a triterpene isolated from Euphorbia lactea latex. Phytomedicine 17: 146-148.

Ferreira JLP, Amaral ACF, Araujo RB, Carvalho JR, Proenca CEB, Fraga SAPM, Silva JRA 2009. Pharmacognostical comparison of three species of Himatanthus. Int J Bot 5 : 171-175. 
Ho JN, Lee YH, Park JS, Jun WJ, Kim HK, Hong BS, Shin DH, Cho HY 2005. Protective effects of aucubin isolated from Eucommia ulmoides against UVB-induced oxidative stress in human skin fibroblasts. Biol Pharm Bull 28: 1244-1248.

Hohmann J, Molnár J 2004. Euphorbiaceae diterpenes: plant toxins or promising molecules for the therapy? Acta Pharm Hung 74: 149-157.

Jin L, Xue H, Jin L, Li S, Xu Y 2008. Antioxidant and pancreasprotective effect of aucubin on rats with streptozotocininduced diabetes. Eur J Pharmacol 582: 162-167.

Kapiszewska M, Soltys E, Visioli F, Cierniak A, Zajac G 2005. The protective ability of the mediterranean plant extract against the oxidative DNA damage. The role of the radical oxygen species and the polyphenol content. $J$ Physiol Pharmacol 56: 183-197.

Lopes MIL, Saffi J, Echeverrigaray S, Henriques JAP, Salvador M 2004. Mutagenic and antioxidant activities of Croton lechleri sap in biological systems. J Ethnopharmacol 95: 437-445.

Lovell DP, Omori T 2008. Statistical issues in the use of the comet assay. Mutagenesis 23: 171-182.

Mavournin KH, Blakey DH, Cimino MC, Salamone MF, Heddle JA 1990. The in vivo micronucleus assay in mammalian bone marrow and peripheral blood. A report of the US Environmental Protection Agency Gene-Tox Program. Mutat Res 239: 29-80.

Medeiros R, Otuki M, Avellar M, Calixto J 2007. Mechanisms underlying the inhibitory actions of the pentacyclic triterpene $\alpha$-amyrin in the mouse skin inflammation induced by phorbol ester 12-O-tetradecanoylphorbol-13acetate. Eur J Pharmacol 559: 227-235.

Milliken W 1997. Traditional anti-malarial medicine in RoraimaBrazil. Econ Bot 51: 212-237.

Nadin SB, Vargas-Roig LM, Ciocca DR 2001. A silver staining method for single-cell gel assay. J Histochem Cytochem 49: 1183-1186.

Nicolaou KC, Montagnon T 2008. Molecules that changed the world, Weinheim: Wiley, p. 366.

Nigam N, Prasad S, Shukla Y 2007. Preventive effects of lupeol on DMBA induced DNA alkylation damage in mouse skin. Food Chem Toxicol 45: 2331-2335.

OECD 1997. Organization for Economic Co-operation and Development. Mammalian Erythrocyte Micronuclei Test. Guideline for the Testing of Chemicals. Updated Test Guideline 474. Paris, France. Available online: www.oecd.org//ehs/test/health.htm\#ADOPTED GUIDELINES

Oliveira F, Chaves M, Almeida F, Limajr R, Silva R, Maia J, Brito G, Santos F, Rao V 2005. Protective effect of $\alpha$ - and $\beta$-amyrin, a triterpene mixture from Protium heptaphyllum (Aubl.) March. trunk wood resin, against acetaminophen-induced liver injury in mice. J Ethnopharmacol 98: 103-108.

Paiva JP, Lima LGS, Siqueira CM, Cardoso JS, Holandino C,
Costa Leitão A 2011. Evaluation of the genotoxic and mutagenic potentials of phytotherapic and homeopathic solutions of Euphorbia tirucalli Lineu (Aveloz). Int J High Dilutions Res 10: 71-72.

Pinto AAC, Maduro CB 2003. Produtos e subprodutos da medicina popular comercializados na cidade de Boa Vista, Roraima. Acta Amazon 33: 281-290.

Rossi D, Bruni R, Bianchi N, Chiarabelli C, Gambari R, Medici A, Lista A, Paganetto G 2003. Evaluation of the mutagenic, antimutagenic and antiproliferative potential of Croton lechleri (Muell. Arg.) latex. Phytomedicine 10: 139-144.

Sequeira BJ, Vital MJS, Pohlit AM, Pararols IC, Caúper GSB 2009. Antibacterial and antifungal activity of extracts and exudates of the Amazonian medicinal tree Himatanthus articulatus (Vahl) Woodson (common name:sucuba). Mem I Oswaldo Cruz 104: 659-661.

Shlamovitz GZ, Gupta M, Diaz JA 2009. A case of acute keratoconjunctivitis from exposure to latex of Euphorbia tirucalli (Pencil Cactus). J Emerg Med 36: 239-241.

Silva JRA 2000. Contribuição ao estudo do látex de Himatanthus sucuuba: Aspectos químicos e farmacológicos. Rio de Janeiro, 261p. Tese de Doutorado, Universidade Federal do Rio de Janeiro.

Silva JRA, Amaral ACF, Siani AC, Rezende CM, Felcman J, Pinto AC 2003. Contribution to the study of Himatanthus sucuuba latex macromolecule, microelements and carbohydrates. Acta Amazon 33: 105-110.

Silva JRA, Amaral ACF, Silveira CV, Rezende CM, Pinto AC 2007. Quantitative determination by HPLC of iridoids in the bark and latex of Himatanthus sucuuba. Acta Amazon 37: 119-122.

Singh NP, McCoy MT, Tice RR and Schneider EL 1988. A simple technique for quantitation of low levels of DNA damage in individual cells. Exp Cell Res 175: 184-191.

Soares DC, Andrade ALS, Delorenzi JC, Silva JRA, Freirede-Lima L, Falcão CAB, Pinto AC, Rossi-Bergmann B, Saraiva EM 2010. Leishmanicidal activity of Himatanthus sucuuba latex against Leishmania amazonensis. Parasitol Int 59: 173-177.

Soares PM, Lima SR, Matos SG, Andrade MM, Patrocínio MCA, Freitas CDT, Ramos MV, Criddle DN, Cardi BA, Carvalho KM, Assreuy AMS, Vasconcelos SMM 2005. Antinociceptive activity of Calotropis procera latex in mice. J Ethnopharmacol 99: 125-129.

Suffredini IB, Daly DC 2004. O Rio Negro como Cenário na Busca de Novos Medicamentos. In Florestas do Rio Negro, p. 257-281.

Sunitha S, Nagaraj M, Varalakshmi P 2001. Hepatoprotective effect of lupeol and lupeol linoleate on tissue antioxidant defense system in cadmium-induced hepatotoxicity in rats. Fitoterapia 72: 516-523.

Tice R 1995. Applications of the single cell gel assay to environmental biomonitoring for genotoxic pollutants. In: Biomonitors and biomarkers as indicators of environmental change, New York: Plenum Press, p. 69- 
79.

Wang J, Wang X, Jiang S, Lin P, Zhang J, Lu Y, Wang Q, Xiong Z, Wu Y, Ren J, Yang H 2008. Cytotoxicity of fig fruit latex against human cancer cells. Food Chem Toxicol 46: 1025-1033.

\section{*Correspondence}

\section{Alexandre de B. F. Ferraz}

Programa de Pós-graduação em Genética e Toxicologia Aplicada, Universidade Luterana do Brasil

Av. Farroupilha, 8001, Prédio 22, $4^{\circ}$ andar, Bairro São José, 92450-900 Canoas-RS, Brazil

alexandre.ferraz@ulbra.br

Fone/Fax: +55 5134779214 